\title{
The Unity of Body and Mind in Xu Fuguan's Theory
}

\author{
Tea SERNELJ*
}

\begin{abstract}
The present article deals with the philosophical theory and epistemological methodology of the Modern Confucian Xu Fuguan (1903-1982), a significant Taiwanese philosopher of the $20^{\text {th }}$ century whose theoretical contributions are in the center of academic interests in China and Taiwan, though almost completely unexplored in the West. The article's main focus is on Xu's interpretation of the concepts of bodily recognition and the creative potential $q i$ that are forming the basis of the unification of body and mind as a fundamental method of traditional Chinese perception of reality. For $\mathrm{Xu}$ Fuguan, this unification represented the proper way to achieve the awareness of the Moral Self and to thoroughly act in accordance with humanness (ren).
\end{abstract}

Keywords: bodily recognition, $q i$, Xu Fuguan, Chinese philosophy, Chinese epistemology

\section{Izvleček}

Pričujoči članek obravnava filozofsko teorijo in epistemološko metodologijo Modernega konfucijanca Xu Fuguana (1903-1982), pomembnega tajvanskega filozofa 20. stoletja, katerega teoretski doprinosi so $\mathrm{v}$ središču akademskega interesa $\mathrm{v}$ kitajsko govorečih regijah, medtem ko so na Zahodu še tako rekoč popolnoma neraziskani. Članek se v glavnem osredotoča na Xujevo interpretacijo konceptov telesnega spoznanja in tvornega potenciala $q i$, katera predstavljata osnovo za združitev telesa in zavesti kot ene temeljnih metod tradicionalne kitajske estetske percepcije resničnosti. Ta enotnost je za Xu predstavljala pot do ozaveščanja moralnega sebstva in do doslednega udejanja sočlovečnosti (ren).

Ključne besede: telesno spoznavanje, qi, Xu Fuguan, kitajska filozofija, kitajska epistemologija

* Tea SERNELJ, PhD Candidate and Assistant Reasercher, Department of Asian and African Studies, Faculty of Arts, Ljubljana tea.sernelj@ff.uni-lj.si 
Just as it is true that everything symbolizes the body, so it is equally true (and all the more so for that reason) that the body symbolizes everything else. (Mary Douglas)

\section{Xu Fuguan and the $2^{\text {nd }}$ Generation of Modern Confucianism}

Xu Fuguan 徐復觀 (1903-1982) was a Chinese intellectual and historian who made important contributions to Modern Confucian studies. Hence, it is not coincidental that he belonged to the philosophical of Modern Confucianism (新儒 學). This stream of thought mainly developed during the $20^{\text {th }}$ century in Taiwan and Hong Kong. It still forms the most influential and important stream of thought in contemporary Chinese theory. It is distinguished by a comprehensive attempt to revitalize traditional (particularly Confucian and Neo-Confucian) thought by means of new influences borrowed or derived from Western systems (see Rošker 2013, 18). It is defined as a search for synthesis between Western and Chinese traditional thought, aiming to elaborate a system of ideas and values, suitable to resolve social and political problems of the modern, globalized world.

Since Modern Confucians viewed modernization mainly as a rationalization of the world, I follow in my research the presumption, according to which Modern Confucianism (as a discourse in which "signposts" for rehabilitation of traditionalism were most clearly expressed), can be considered as originating with the famous Declaration for a renewed valuation of Chinese culture as a world heritage (為中國文化敬告 世界人士宣言), which was published by a group of philosophers from Taiwan and Hong Kong, on January 1, 1958 (Rošker 2013, 20). Besides $\mathrm{Xu}$, who's aesthetic and epistemological work will be introduced below, the key undersigners of the declaration were Carsun Chang (Zhang Junmai 張君勱, 1887-1969), Mou Zongsan 牟宗三 (1909-1995) and Tang Junyi 唐君毅 (19091978). These theoreticians are still widely regarded as the founders of Modern Confucianism, understood as a system which provided a more systematic reinterpretation of traditional Chinese philosophy based on a profounder and more integral command of the foundations of Western, especially Platonic, Kantian and Hegelian, thought. Most of them are regarded as representatives of the so-called 
second generation of Modern Confucians which includes - according to the most prevailing categorization - the following theoreticians:

1. Mou Zongsan 牟宗三 (1909-1995)

2. Tang Junyi 唐君毅 (1909-1978)

3. Xu Fuguan 徐復觀 (1903-1982) and

4. Fang Dongmei 方東美 (1925-1948)

They dealt extensively with problems, linked to the Chinese modernization. This process was regarded by the majority of them as a rationalization of the world. In search of their philosophical basis they mostly focused upon the question of ontology which they usually formed in the frame of the newly investigated Western systems of thought. Generally, they derived from the premise that the questions of innermost reality of the Universe, of the substance of being and of the Absolute are the questions that determine the meaning of life. As such, these questions were essential for the establishment of new value systems, adjusted to the requirements and conditions of modern societies and, on the other hand, for the preservation of the integrated, unalienated cultural and personal identity of the individuals in China.

The intellectual stream of Modern Confucianism emerged from the attempt to synthesize Western and traditional thought. However, these attempts were defined with the crisis of both types of discourses. The ideals of Modern Confucians were not limited to the attempt for revitalization and rehabilitation of ideological traditions from which they derived; it was obvious that they could entice the modernization of Confucianism only on the basis of its fusion with ideas "imported" from abroad, i.e. from the very areas in which the modernization processes were emerging.

Their efforts were not merely to save their own tradition, but also to find a solution for the foreign ideological tradition, which had been irrevocably entangled into its own philosophical traps.

In general, the members of the second generation have attempted to find new methods for a revitalization of their own cultural identity in the sense of "transplanting old roots" of their own tradition, because in their view, such a revival was the only possible way for the survival of the cultural tradition, from which they were a part, and which suffered under pressures and challenges of Western cultures. This renovation of the "root" should not merely serve for the 
survival of their own cultural identity, but should - if carried out conscientiously and accurately enough - also offer the stream of Modern Confucianism an active and innovative role of becoming the leading current of modernized Chinese thought and as the leading force in intercultural dialogues between contemporary societies.

\section{The Complementary Relation of Body and Mind}

For Xu Fuguan, the traditional Chinese interconnection of body and mind was closely linked to the concept of anxiety (youhuan yishi 憂患意識) which also belonged to the central problems investigated in his theoretical work (Sernelj 2013, 650). This connection can already be seen in several quotations from Zhuangzi 莊 子, one of Xu Fuguan's favorite ancient philosophers:

\section{三患莫至，身常無殊.}

If one manages to escape from the three forms of concern, his body will always remain free from misfortune (Zhuangzi 2013, Waipian, Tiandi, 6).

In another important ancient Daoist work, namely in Laozi's 老子 Daodejing 道德 經 for instance, we also come across the following statement, implying the same connection:

\section{吾所以有大患者，為吾有身，及吾無身，吾有何患？}

What makes me concerned is the fact that I own a body. Without having a body, what concerns could I have? (Laozi 2013, 13)

In his main work The Spirit of Chinese Art (Zhongguo yishu jingshen 中國讛術精 神), Xu Fuguan also repeatedly pointed out that the body is in the center of Confucian interest; most of the Confucian philosophers found their theoretical models upon the direct presence of the body and physical discipline, although they always end with their central attention directed towards men's social duties (Liu 2008, 578). Mengzi 孟子, for instance, laid stress on the fact, that the body is the beginning of all human existence, including their social worlds:

天下之本在國，國之本在家，家之本在身。

Man always links the world, the country, and the family together when he talks; the world is based on the country and the country on families, while family is based on the body (Mengzi 2013, Li lou shang, 5) 
A similarly fundamental role has been prescribed to the body in the Book of Rites 禮記 ( $L i ~ j i)$, one of the most important Confucian classics. In this work, we also often come across its relation to the mind (in the sense of $x i n$, i.e. 心 heart-mind or consciousness):

心正而後身修，身修而後家齊，家齊而後國治，國治而後天下平。

Only after the heart-mind has been properly settled, the body can be cultivated. The cultivation of the body makes then the regulation of the family possible, which preconditions a good government. A good government, again, is a precondition for the world peace ( $L i j i$ 2013, Da xue, 2).

This quotation shows very clearly that the mind is seen as having priority (or being more fundamental) to the existence over the body. Similar statements can be found throughout the entire Chinese intellectual history, although in denoting the body, the concept shen 身 has mostly been replaced by the concept of $q i$ 氣 which was very precisely and in great details investigated by Xu Fuguan in his abovementioned work (2001).

Because of the differences in the linguistic and philosophical development, the traditional Chinese concept of body differs from the one that was established in the Western historical development. It can be expressed in various ways, implying numerous different semantic connotations which cannot always exactly match to the Western ones. The above-mentioned notion shen 身, for instance, can denote a (human or animal) body. In addition, however, it can also denote the individual or a personality. In its verbal form, it can even mean personal experience of some individual human being, his or her life, or even his or her own moral character and ability (see CTP Dictionary). The body in the Western sense, however, could be even better translated with the notion xueqi 血氣, as it can be seen in the following quotation from the Book of Rites:

\section{夫民有血氣心知之性.}

Now, in the nature of men there are both the physical powers and the intelligence of the mind. (Li ji 2013, Yie ji, 27)

Here, the binary anti-pole of the concept xueqi (literary: blood and vital energy) is represented by the notion xinzhi 心知 (literary: heart and knowledge).

That which is in the center of Xu Fuguan's interest, however, is the relation between the concept $q i$ 氣 in the sense of an organism (i.e. an organic body) and 
the concept xin 心 in the sense of consciousness or human heart-mind. Although the earliest missionaries, who were in China translating the philosophical works of the Chinese tradition, have mostly translated it as a form of matter, i.e. a pure physical entity (Rošker 2012, 275), it is evident that the concept qi can hardly be understood as a matter in the "Western" sense. In fact, the Neo-Confucian philosophers defined it as something which is not necessarily substantial, as air or even a vacuum (the Great void 太虛) is composed of it. Thus, it represents a concept which could be more appropriately defined as creativity, or a potential that functions in a creative way and which can appear in some material sphere, but also in the abstract realm of ideas:

\section{氣之聚散於太虛由冰釋於水.}

In the Great void, $q i$ condenses and dissolves again. This can be compared to ice dissolving in water. (Zhang 1989, 389)

As noted, the majority of traditional European and American sinologists have translated this concept as "matter" (Graham 1992, 59). To illustrate this aspect, we can quote the translation of this passage by the well-known French sinologist from the beginning of the $19^{\text {th }}$ century, Le Gall, in which the notion $q i$ is clearly understood as atom(s): “

Le condensation et les dispersions des atomes dans la T'ai-hiu peuvent se comparer a la fonte de la glace dans l'eau. (Le Gall in Graham 1992, 60)

Such translation of the concept qi is questionable, because it derives from profoundly incorporated criteria, of the model of Cartesian dualism. Although Zhang Zai's comparison with water explicitly states that qi is a continuous state, and not an aggregate of atoms, the analogy with "matter" was so deeply rooted in Le Gall's perception, that he automatically saw the notion qi as an entity which contains or is composed of atoms (Rošker 2012, 276). Hence, for centuries, Le Gall and other sinologists who followed his interpretations have misled scholars regarding the question whether traditional Chinese philosophy applied the concept of atomicity (Graham 1992, 61).

This creative potential, which can, as already mentioned, appear in both the material as well as in the ideal sphere, and which has been most often denoted in the contemporary esoteric New Age literature simply as "energy", or at the most, as a "vital energy". This could possibly be understood as a kind of dynamic organic potential or-depending on the context-an organic body, i.e., an 
organism. Given the fact that all Modern Confucians, including Xu Fuguan, were proceeding from the onto-epistemological notion of the immanent transcendence, the concept qi could, in this understanding, be viewed as possessing a double ontology. Thus, when appearing in the concrete sphere of life it is incorporated in the sense of a living body, and at a transcendental level it manifests itself as a creative potential, enabling and preserving physical life.

Since in Chinese philosophy, central concepts seldom appear alone or independently, but rather in the framework of the so-called binary categories (duili fanchou 對立範疇) (Rošker 2012, 280), the concept $q i$ has also mostly appeared linked to an anti-pole, as for instance within the binary category qi-zhi 氣志 (vital or creative potential and human will, as applied by Mengzi 孟子 and Xunzi 荀子), or $l i$-qi 理氣 (structure and creativeness, as applied by $\mathrm{Zhu} \mathrm{Xi}$ 朱喜). In the present context which regards the relation between body and mind, it has naturally been applied in a binary qi-xin 氣心, whereas the former could be (rather freely, of course) associated with the body, and the latter with the mind.

Although binary categories always function in a mutually complementary way which means that they are interdependent and mutually completing one another, the primary role among them has in Chinese tradition most often been prescribed to the concept of mind or heart-mind (xin 心). This has been exemplified in the above cited quotation from the chapter "Daxue" 大學 of the Book of the Rites which clearly showed that the cultivation of the body was preconditioned by a "proper state" of the (heart-) mind. Similarly, Mengzi also exposed the primary role of the will in connection to the body, pointing simultaneously to the relation between the two aspects of the body, namely of $q i$ 氣 in the sense of a vital creativity which revives the physical body $t i$ 體 $^{1}$.

夫志，氣之帥也；氣，體之充也。

The will is the leader of the vital organism, which pervades and animates the (physical) body. (Mengzi 2013, Gonsong Chou I)

When introducing the concept $q i$ 氣 (in the sense of an organism) into this binary relation with the heart-mind, the latter concept mostly still remains placed on a prior position throughout the entire Chinese intellectual history.

\footnotetext{
${ }^{1}$ In classical Chinese worldview, $q i$ 氣 as the principle of organic creativity was seen as the very vital potential which animated the physical body $t i$ 體 and which actually brought it to life.
} 
In his famous Chun qiu fanlu 春秋繁露, for instance, Dong Zhongshu 董仲舒 clearly states:

凡氣從心。心, 氣之君也.

Qi is always following the heart-mind. The heart-mind is the ruler of the Qi.

(Zhongshu, Xun tian zhi dao)

This priority, however, by no means remained limited to Confucian sources. Even the egalitarian Daoist philosophers have often pointed out that

心之所之, 則氣從之; 氣之所之, 則形應之。

Wherever the heart-mind is pointing, the Qi has to follow it; and wherever the

Qi is pointing, the form has to adjust to it (Wen shi zhenjing 2013, Wu yan, 15)

On the other hand, however, the heart-mind has thoroughly been seen as a part of the body. Its ability to "think" comes from the body's changing of its function from that of a physical organ to that of a mental organ (Liu 2008, 579). See, for example, Mengzi's view on this relation:

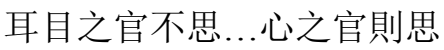

The organs such as the ears and eyes cannot think [...] the function of the heart is to think. (Mengzi 2013, Gaozi shang, 15)

It is quite obvious that the heart-mind (i.e. the consciousness and the central cognitive tool) was understood as one of the (although highly developed) bodily organs.

In this regard, the relation between body and mind (or qi and xin) can still be considered as a complementary structured unity.

\section{Bodily Recognition and Embodiment of Moral Subjectivity}

$\mathrm{Xu}$ Fuguan was practically the only representative of the second generation of Modern Confucians who considered that metaphysics and ontology were not appropriate instruments for understanding ancient Chinese thought, and much less for the development of its interpretation, because, according to him, its pragmatic nucleus never led to any composition or any structured and coherent conception of a metaphysical system, as had been established, for instance, by the ancient Greek philosophers (see Xu 2001, 43ff). Instead, ancient Chinese philosophers developed an idea of ethics, based on the "divine or heavenly" essence of human beings, 
directly from the "primitive" state of religious and mythological society. (Sernelj 2013b, 73)

$\mathrm{Xu}$ argued that we can't find anything similar to the Western metaphysic tradition in Chinese philosophy. On the contrary, one of the basic characteristics of Chinese philosophy is immanent transcendence which means that everything that appears in the abstract sphere can exist - at least possibly - also at the physical level. He places the binary category of the heart-mind on the one, and the body at the other, and at the center of both, human reasoning and the cosmos. He states:

Although the "heart" mentioned in Chinese culture refers to a part of the five physiological organs, China regards the heart's functions as where life's values originate, as we regard our ears as where our sound - hearing and color-distinction originate. Mencius takes ears and eyes as "small bodies" because their functions are of small significance, and heart as a "great body" because its functions are great. Great or small, however, they are at one in that they are all parts of human physiological functions. Can we then talk of this physiological part as a mind of Western idealism? Does the West's idealistic mind refer to our physiological part? There may be traces left of our heart if we relate "heart" in China to Western materialism, for physiology is something materialistic and the heart's functions are works of physiology, yet there would be no trace left at all of the heart if we relate it to idealism. (Xu 1975, 243 in Huang 2010)

He suggests that Chinese philosophy and the heart-mind culture should be considered as a mesophysics rather than metaphysics not only because of the above mentioned characteristics of Chinese philosophy, but also because of the physiological basis and implications of the heart's functions for value (and moral) judgments. (Huang 2010)

$\mathrm{Xu}$ followed Mencius' distinction between great man (junzi 君子) and small man (xiaoren 小人) which includes understanding of the body and its functions as a great (dati 大體) and small parts (xiaoti 小體) of the body in the following way:

公都子問曰:「鈞是人也，或為大人，或為小人，何也？」

孟子曰:「從其大體為大人，從其小體為小人。」

曰:「鈞是人也，或從其大體，或從其小體，何也？」

耳目之官不思，而蔽於物，物交物，則引之而已矣。心之官則思，思則 得之, 不思則不得也。此天之所與我者, 先立乎其大者, 則其小者弗能 奪也。此為大人而已矣 (Mengzi 2013, Gaozi I) 
The disciple Gong Du asked, "Though equally human, why are some men greater than others?"

Mengzi answered: "He who is guided by the interest of the parts of his person that are of greater importance is a great man; he who is guided by the interests of the part of his person that are of smaller importance is a small man."

The disciple asked: "Though equally human, why are some men guided one way and others guided another way?"

Mengzi replied: “The senses of hearing and seeing do not think, and are obscured by external things. When one thing comes into contact with another, as a matter of course it leads it away. To the mind belongs the office of thinking. By thinking, it gets the right view of things; by neglecting to think, it fails to do this. These - the senses and the mind - are what Heaven has given to us. Let a man first stand fast in the supremacy of the nobler part of his constitution, and the inferior part will not be able to take it from him. It is simply this which makes the great man."”

What Mencius called the great body is the reasoning performed by our bodily heart-mind which consists of the enduring quest for self-improvement and selfcultivation. This self-cultivation is regarded as a cultivation of the body. Ito Togai exposed:

When people have this heart, there will be this affair. When there is this affair, it can be out of this heart. Is there a shooting? It is this heart shooting. Riding? It is this heart riding. Writing letters? It is this heart writing. However, if we merely concentrate on this one heart, pondering on how to train it, without the body exercising such affairs, we would end up being unable to shoot, ride or write letters, while the heart remains their lord and leader. So, the sage's teachings often talk about the body without talking about the heart, because within the talk of the body there naturally are the heart's operations. Thus, what they say about humanity, rightness, ritual-decency and music, is all about affairs of cultivation of the body. (Ito in Huang 2010, 32-33)

In Mengzi's words, if we want to become a great man, we should think with our bodily heart-mind and avoid perceiving the world only by senses. In such a way, the body becomes the manifestation of spiritual cultivation:

君子所性，仁義禮智根於心。其生色也，睟然見於面，盎於背，施於四 體，四體不言而喻。」(Mengzi 2013, Jin xin shang, 21)

That which a gentleman follows as his nature, that is to say, benevolence, rightness, the rites and wisdom, is rooted in his heart, and manifests itself in his face, giving it a sleek appearance. It also shows in his back and extends to his limbs, rendering their message intelligible without words. 
Since according to Mengzi, our body and its complexion are given to us by Heaven, only a sage can give his body complete fulfillment (Huang 2010, 33). Xu Fuguan also argues that Confucius obtained the Decree of Heaven or moral decree through bodily recognition (tiren 體認). According to him, tiren is a retrospective and active process in which "the subject uncovers moral subjectivity from the pseudo-subjectivity of human desires and affirms it, develops it". One reveals one's own moral nature through "overcoming the self" and "reducing sensual desires." By freeing oneself from these constraints, the subject lets the original mind emerge. The way to determine what desires and inclinations need to be overcome is the same as the way to reveal moral subjectivity: bringing whatever feelings and ideas that one experience before the light of moral subjectivity in one's own heart-mind, and seeing whether one can still take the feelings and ideas at ease. (Ni 2002, 289)

$\mathrm{Xu}$ agrees with the Cheng brothers and with Wang Yangming that there exists the identity of the Heaven and the human heart-mind which can be directly experienced through bodily recognition. If so, the Heaven and its moral implications are not something abstract to human beings, but rather something implemented in our physiological and psychological structure. Therefore, we are able to reduce the sensations and feelings that are not following the way of the heart-mind to achieve the unity of the Heaven as the moral instance and the human nature (Ni 2002, 289). The method of achieving such unity is the learning for the self (weiji zhi xue 為已者學) which is not the learning merely to understand others but rather serves for discovering, opening, transforming and completing oneself through which one turns the biological self into moral, rational and artistic self.

\section{Conclusion}

For Xu Fuguan, who has thoroughly laid stress upon the role and the function of the ethical nucleus of ancient Chinese worldview, the reduction of pure sensory perception was a central factor which enabled humans to achieve higher levels of self-completion. According to him, humans become able to reduce such purely instinctive perception, because their bodies are inherently connected with their heart-minds. This unity enabled them to follow the "significant", i.e. benevolent, justified, ritualized and wise paths of social practice, instead of following the "insignificant", i.e. instinctive, egoistic and egocentric ways of individual benefits. Because for him, tiren (bodily recognition) is a method of achieving the complex 
manifestation of the moral character and the realization of ren 仁 (humanness), this kind of perception is one of the central features dividing humans from other living creatures.

\section{References}

CTP Dictionary. 2013. In Chinese Text Project. Accessed November 20, 2013, http://ctext.org/dictionary.pl?if=en\&char=\%E8\%BA\%AB.

Dong, Zhongshu 董仲舒. Chun qiu fanlu 春秋繁露 (The Rich Dew of the Spring and Autumn Annales). In Chinese Text Project. Accessed November 20, 2013, http://ctext.org/chun-qiu-fan-lu.

Douglas, Mary. 1978 (1966). Purity and Danger. London: Routledge and Kegan Paul.

Graham, A.C. 1989. Disputers of the Tao - Philosophical Argument in Ancient China. Chicago: Open Court Publishing.

- 1992. Unreason within Reason - Essays on the Outskirt of Rationality. Lasalle, Illinois: Open Court Publishing.

Huang, Chun-chieh, 2010. Humanism in east Asia Confucian Context. Bielefeld: Transcript Verlag.

Laozi 老子. 2013. Daode jing 道德經 (The Book of the Way and the Virtue). In Chinese Text Project. Accessed November 20, 2013, http://ctext.org/dao-de-jing.

Li ji 禮記 (The Book of Rites). 2013. In Chinese Text Project. Accessed November 20, 2013, http://ctext.org/liji/da-xue?searchu=\%E8\%BA\%AB.

Liu, Chengji. 2008. "The Body and its Image in Classical Chinese Aesthetics." Frontiers of Philosophy in China 3(4), December: 577-94.

Mengzi 孟子. 2013. Mengzi 孟子 (Master Meng). In Chinese Text Project. Accessed November 20, 2013, http://ctext.org/mengzi/li-lou-i?searchu=\%E8\%BA\%AB.

$\mathrm{Ni}$, Peimin. 2002. "Practical Humanism of Xu Fuguan." In Contemporary Chinese Philosophy, edited by Chung-Ying Cheng and Nicholas Bunnin, 281-304. Oxford: Blackwell Publishers.

Rošker, Jana S. 2012. "Structure and Creativeness: A Reinterpretation of the NeoConfucian Binary Category Li and Qi." In Origin(s) of Design in Nature: A Fresh, Interdisciplinary Look at How Design Emerges in Complex Systems, Especially Life, Vol. 23 of Cellular Origin, Life in Extreme Habitats and Astrobiology, edited by Liz Stillwaggon Swan, Richard Gordon, and Joseph Dordrecht Seckbach, 273-85. London, New York: Springer.

—. 2013. Subjektova nova oblačila - teorije modernizacije v delih druge generacije modernega konfucijanstva. Ljubljana: ZIFF 
Sernelj, Tea. 2013a . "Contemporary Modern Confucianism and Xu Fuguan's Concepts of Anxiety and Bodily Recognition. In Philosophy as Inquiry and Way of Life, p. 650. Athens: University of Athens, School of Philosophy.

—. 2013b. "Xu Fuguan's Concept of Anxiety and Its Connection to Religious Studies." In Asian Studies 1(2): 71-87.

Wen shi zhen jing 文始真經 (The Genuine Classics of the beginning of Culture). 2013. In Chinese Text Project. Accessed November 20, 2013, http://ctext.org/pre-qin-andhan?searchu=\%E5\%BF\%83\%E4\%B9\%8B\%E6\%89\%80\%E4\%B9\%8B .

Xu, Fuguan 徐復觀. 2001. Zhongguo yishu jingshen 中國㙯術精神 (The Spirit of Chinese Art). Beijing: Huadong shifan daxue chuban she.

Zhang, Xuezhi. 2007. "Several Modalities of the Body-mind Relationship in Traditional Chinese Philosophy." Frontiers of Philosophy in China 2(3): 379-401.

Zhang, Zai 張載. 1989. Zheng meng 正蒙 (Correction of Ignorance), Vol. 4 of Xingli da quan, Kongzi wenhua da quan, edited by Hu Guang. Jinan: Shandong youyi shu she.

Zhuangzi 莊子2013. Zhuangzi 莊子 (Master Zhuang). In Chinese Text Project. Accessed November 20, 2013, http://ctext.org/zhuangzi?searchu=\%E6\%82\%A3\&page=2. 